\title{
Deep Chlorophyll Maximum in Western Equatorial Atlantic - How does it Interact with Islands Slopes and Seamounts?
}

\author{
Tarcisio A. Cordeiro, ${ }^{1, *}$, Fre de rico P. Brandini ${ }^{2}$, Ricardo S. Ros a ${ }^{1}$, Roberto Sass ${ }^{1}$ \\ ${ }^{1}$ Department of Sy stematics and Ecology, Federal University of Paraíba, João Pessoa, 58059-900, Brazil \\ ${ }^{2}$ Oceano graphic Institute, University of São Paulo, São Paulo, 05508-120, Brazil
}

\begin{abstract}
This paper investigates the dynamics of the deep chlorophyll maximum layer (DCML) along the Fernando de Noronha Ridge in the oligotrophic western equatorial Atlantic off northeast Brazil. Mixing processes between water masses above and below the thermocline may occur in a scale of tens of meters around the 24.5 to 25.5 isopycnals, where photoautotrophs are concentrate at the bottom of the euphotic zone. The primary production at the DCML can provide $210( \pm 170)$ metric tons of Carbon per day to the benthic community at the Rocas atoll. The behavior of isopycnals in deeper and strongly stratified waters suggest that internal waves may improve primary production, by lifting the deeper and nutrient-rich South Atlantic Central Water upwards and carrying the autotrophs to brighter depths.
\end{abstract}

Keywords Deep Chlorophyll Maximum, Rocas Atoll, Northeast Brazil, Western Equatorial Atlantic

\section{Introduction}

The upper layers of tropical and subtropical ocean basins are physically stratified with a shallow mixed layer over the main pycnocline, along which deep chlorophyll maximum layers are always detected and maintained through the balance between the growth of pico-sized photoautotrophs and losses by grazing[1]. This are usually dominated by picosized flagellates and the phototrophic cyanobacteria Synechoccocus and Prochloroccocus, which have been reported to account for most of the autotrophic biomass in the oceanic basins[2, 3], particularly Prochloroccocus marinus which may account for 50 to $80 \%$ of the planktonic primary production in tropical and subtropical oceans, growing well adapted to extremely low light intensities at deeper euphotic layers $[4,1,5]$. The global distribution of the Prochloroccocus species makes them an important step of the oceanic biological pump.

However, besides the understanding about the role of the DCML for the oceanic carbon budget it is also necessary to know its spatial dynamics at regional scales. Particularly, how is it affected by the interactions between hydrography and the topographic features like island slopes and seamounts? Does the DCML improve the productivity of the benthic communities? This investigation describes a

* Corresponding author:

tacordeiro@dse.u fpb.br (Tarcisio A. Cordeiro)

Published online at http://journal.sapub.org/ms

Copyright (C) 2013 Scientific \& Academic Publishing. All Rights Reserved conspicuous deep chlorophyll maximum layer along the pycnocline over the Fernando de Noronha Ridge (FNR) in the western equatorial Atlantic and discuss some local processes that may affect the local carbon flow.

\section{Material and Methods}

\subsection{Study Area}

The Fernando de Noronha Ridge (FNR) off northeast Brazil is a chain composed by seamounts, one guyot, atoll and islands, aligned in an approximate east-west direction, extending fro $32^{\circ}$ to $36^{\circ} \mathrm{W}$ and at $3^{\circ}$ to $4^{\circ} \mathrm{S}$ (Fig.1). For a long time this chain was considered as a branch of the mid Atlantic ridge; nevertheless, more recent authors, ex. [33] and references inside, assumed that the ridge was formed by the passage of the South-American plate over a hotspot. Fernando de Noronha Archipelago and Rocas Atoll are only two peaks of this submarine mountain system, rising $4 \mathrm{~km}$ from the ocean floor. Together they make up $>50 \%$ of the insular South Atlantic coastal area surrounded by clear and warm oligotrophic waters of the South Equatorial Current. The benthic system maintains a significant part of the marine biodiversity for the entire South Atlantic basin and support important breeding and feeding grounds of reef fishes, tuna, shark, turtle, marine mammals and the largest concentration of seabirds in the Western Atlantic[34]. A highly diverse benthic community colonizes the islands slopes $[6,7]$, in Rocas coralline algae is the main atoll's building frame.

Water physical stratification in the upper layers is kept by 
the convergence of Equatorial Surface Water (ESW) carried into the study area from east by the Atlantic South Equatorial Current (ASEC), and keeping year-round upper layers with water temperatures and salinities of $>20^{\circ} \mathrm{C}$ and $>35,5$, respectively $[8,9,10,11]$. Lower salin ities at the very surface waters are due to the high precipitation at the intertropical convergence zone $[8,10]$. High salinity (up to 37 ) maximu m deep layers are formed at surface through intense evaporation in the region known as the Southern South Equatorial Current (SSEC), which is feed by the Benguela Current westwards drift ( 8 to $25^{\circ} \mathrm{S}$ off the African coast), it follows the thermocline in the $\sigma=24.5$ to 25.5 isopycnal range[11]. Low nutrient concentrations in the upper mixed layers keep low rates of primary production with mean integrated chlorophyll concentrations $<50 \mathrm{mg} \cdot \mathrm{m}^{-2}[12,13]$ most of which concentrated along the pycnocline. Reference [14] reported that these deep chlorophyll maximum layers are dominated by the picocyanobacteria of the genus Prochlorococcus, growing between 77 and $120 \mathrm{~m}$ and being well adapted to extremely low light intensities, about 1 to $0,1 \%$ of surface light.

\subsection{Field Sampling}

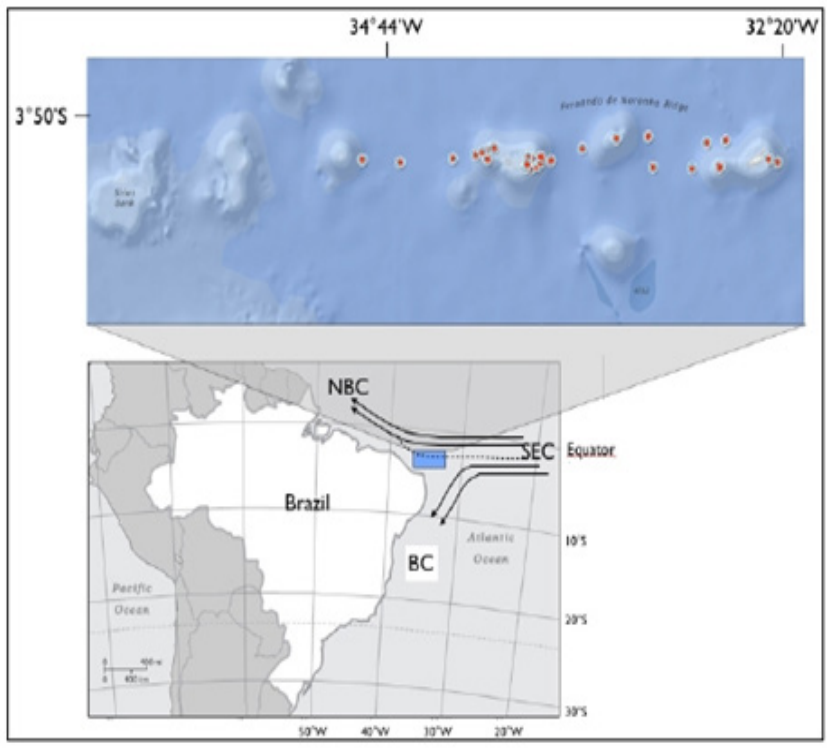

Figure 1. Position of the oceanographic stations

A quasi-synoptic survey was conducted from 11 to 30 March 1999 along the FNR with the R/V Seward Johnson (Harbor Branch, USA, cruise SJ9902) under an international partnership between the Rosenstiel School of Marine and Atmospheric Science, Miami, USA and the Federal University of Paraíba, Brazil. A total of 27 hydrographic stations were made in the eastern half of the ridge between Lat. $34^{\circ} 44^{\prime}$ to $32^{\circ} 20^{\prime} \mathrm{W}$ (Fig. 1). From all stations, 13 were sited over the slopes of Rocas atoll in the middle of the ridge transect and 2 stations over the east slope of FNA. Stations 17 and 23 were sited over seamounts between FN and Rocas. At each station vertical profiles of temperature and salinity were obtained in the upper $200 \mathrm{~m}$ layers with a Seabird 911 CTD, from which density (as sigma-t) was calculated according to[15]. The chlorophyll profiles were obtained with a SeaTech fluoro metric sensor attached to the CTD.

\section{Results}

The $\mathrm{T} / \mathrm{S}$ diagram for all stations from surface down to 200 meters shows the presence of a strong thermocline in the Equatorial Surface Waters (ESW) with salinities $>35,5$ and temperatures $>20^{\circ} \mathrm{C}$. Below the thermocline the South Atlantic Central Waters (SACW) was present, with temperatures ranging from 11,3 to $20^{\circ} \mathrm{C}$ and salinity from 35,5 to 36,4 . So me thermohaline pairs with salinity below 35,5 were found at surface of the stations 1,27 and 2, indicating the occurrence of rain (Fig 2).

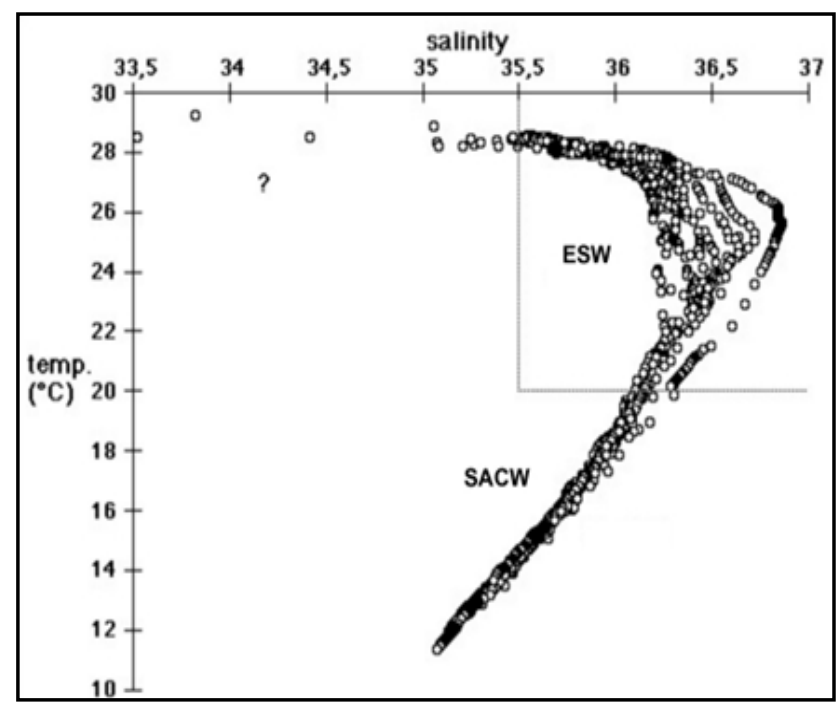

Figure 2. T-S diagram of 2570 thermohaline pairs

Water temperatures were homogeneously distributed in the upper mixed-layer, ranging from 27 to $28^{\circ} \mathrm{C}$, from surface down to 50 meters, from where a steep thermocline extends down to $100 \mathrm{~m}$ (Fig.3). A salin ity maximum layer is formed between $50-100 \mathrm{~m}$ (Fig.4), this subtropical salinity maximum (SSM) is common in the western equatorial Atlantic and has been detected in our study area between 55$115 \mathrm{~m}$ by[10]. Below the SSM, salinities tend to homogenize vertically rag ing between 35-35.5, within the limits typical for the SACW in this region[8, 11]. Salinity affected remarkably the physical stratification, decreasing thickness of the mix layer to $<25 \mathrm{~m}$, increasing gradually water density (as sigma-t) downwards below 25 meters and reaching maximum densities between 100 to $150 \mathrm{~m}$ (Fig.5). Chlorophyll concentrations plotted over the density data against depth shows DCML as a permanent feature of the study area between 50 and 100 meters, coinciding with densities between 25.5 to 26.5 (Fig.6). Fo llowing the overall vertical pattern described above for the whole study area, an upper warm $\left(26-28^{\circ} \mathrm{C}\right)$ and less saline (35.5-36) layer extended along the whole east-west transect above the SSM of 36.2 to 36.4 between $50-75 \mathrm{~m}$ (Fig. 7A). From this down to 200 meters salin ities decreased fast to $36-35$ indicating the 
top limit of the SACW. To the west of Rocas atoll the SSM deepened to $60-100 \mathrm{~m}$ with salinities ranging from 36.4 to 36.8 (Fig.7B). Overall the density field followed closely the temperature distribution (Fig.7C), except along the SSM where salinity contributes to intensify the pycnocline gradients. The vertical stretching of isopycnals was clearly observed westwards from Rocas atoll.

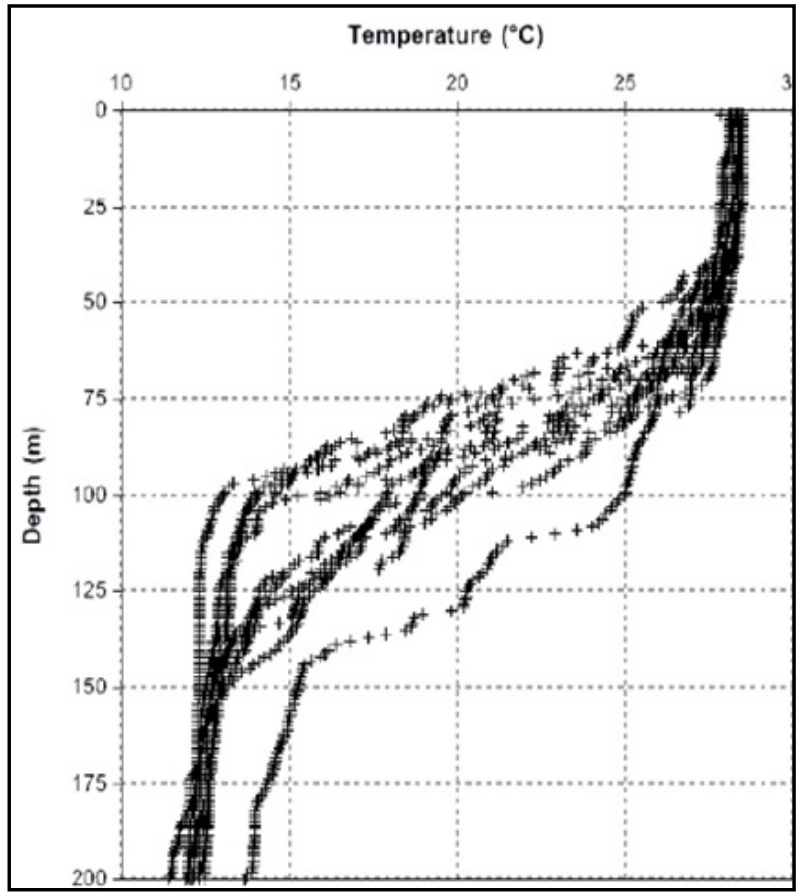

Figure 3. Vertical profiles of temperature

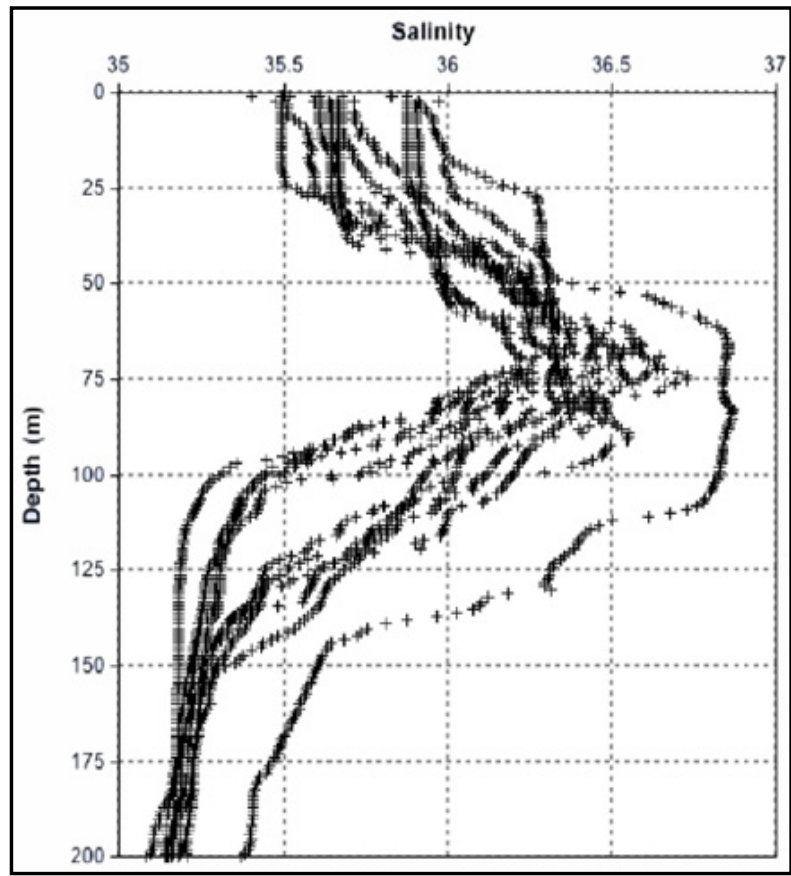

Figure 4. Vertical profiles of salinity

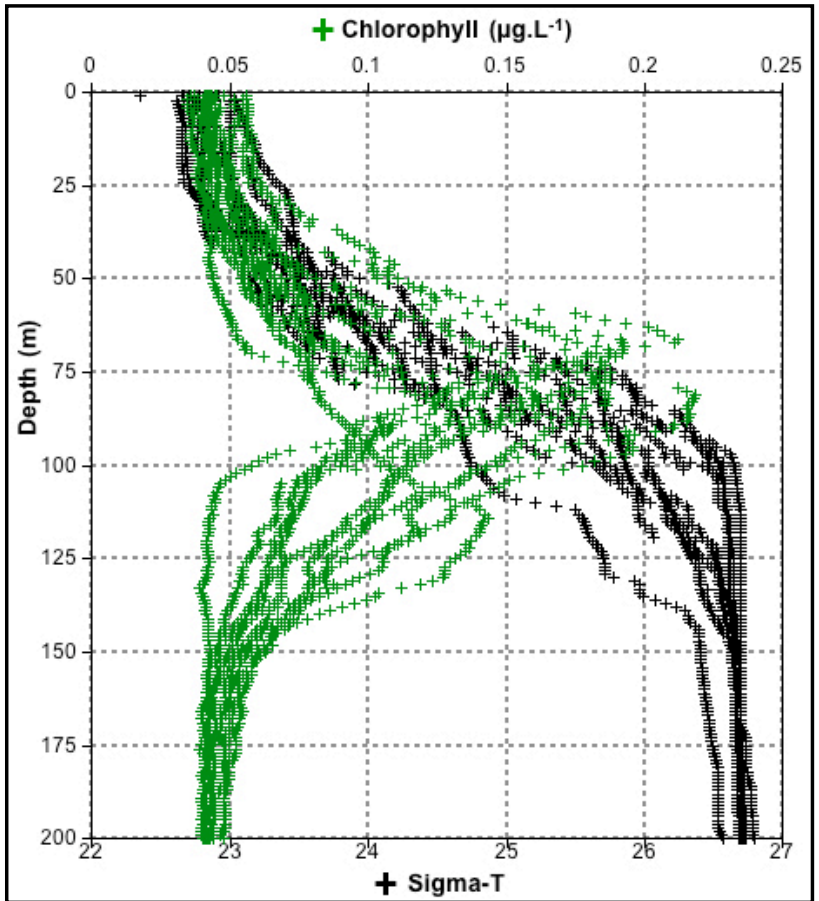

Figure 5. Vertical profiles of chlorophyll and density (sigma-t)

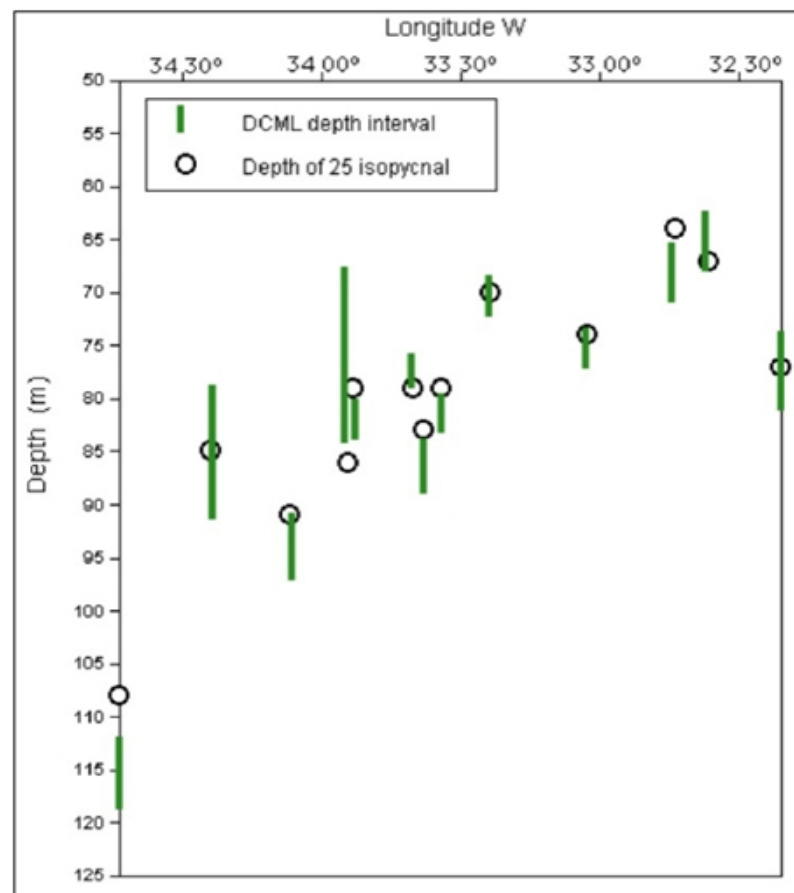

Figure 6. DCML and 25 isopycnal depths along the transec

Mean chlorophyll concentrations at the upper mixed layer ranged between 0,03-0,06 $\mu \mathrm{g} . \mathrm{L}^{-1}$ increasing down- wards up to $>0,2 \mu \mathrm{g} . \mathrm{L}^{-1}$ centred around the 25 isopycnal. The dominated deep chlorophyll maximum layers were detected between 50-100 $\mathrm{m}$ (Fig.7D). Thickness of the deep chlorophyll maxima changed horizontally along the 
east-west transect, with minor peaks ranging from $0.12-0.15$ $\mu \mathrm{g} . \mathrm{L}^{-1}$ at most stations and major peaks of $>0.15 \mu \mathrm{g} . \mathrm{L}^{-1}$ in the westward from FN and Rocas at stations 20, 12, 2 and 27. The highest chlorophyll concentration of $0.21 \mu \mathrm{g} . \mathrm{L}^{-1}$ was detected in the deep maximum of station 20 westward off FN. In the wake side off Rocas mean chlorophyll concentrations in the 25-70 m layers was much higher than upstream. A gradual deepening of the DCML was observed starting from 60-70 meters at stations 20 and 19 , from $80-90$ meters around the atoll's slope and from $112-118 \mathrm{~m}$ in the west end of the sampling transect (Fig.7D).

A vertical fluctuation of the 25.5 isopycnal was better observed in three different surveys around the Rocas atoll, ranging from 81 to $105 \mathrm{~m}$. In an interval of few days, the pycnocline changed depth and shape, resembling the movement of internal waves and carrying the DCML up and down in the euphotic zone (Fig.8)

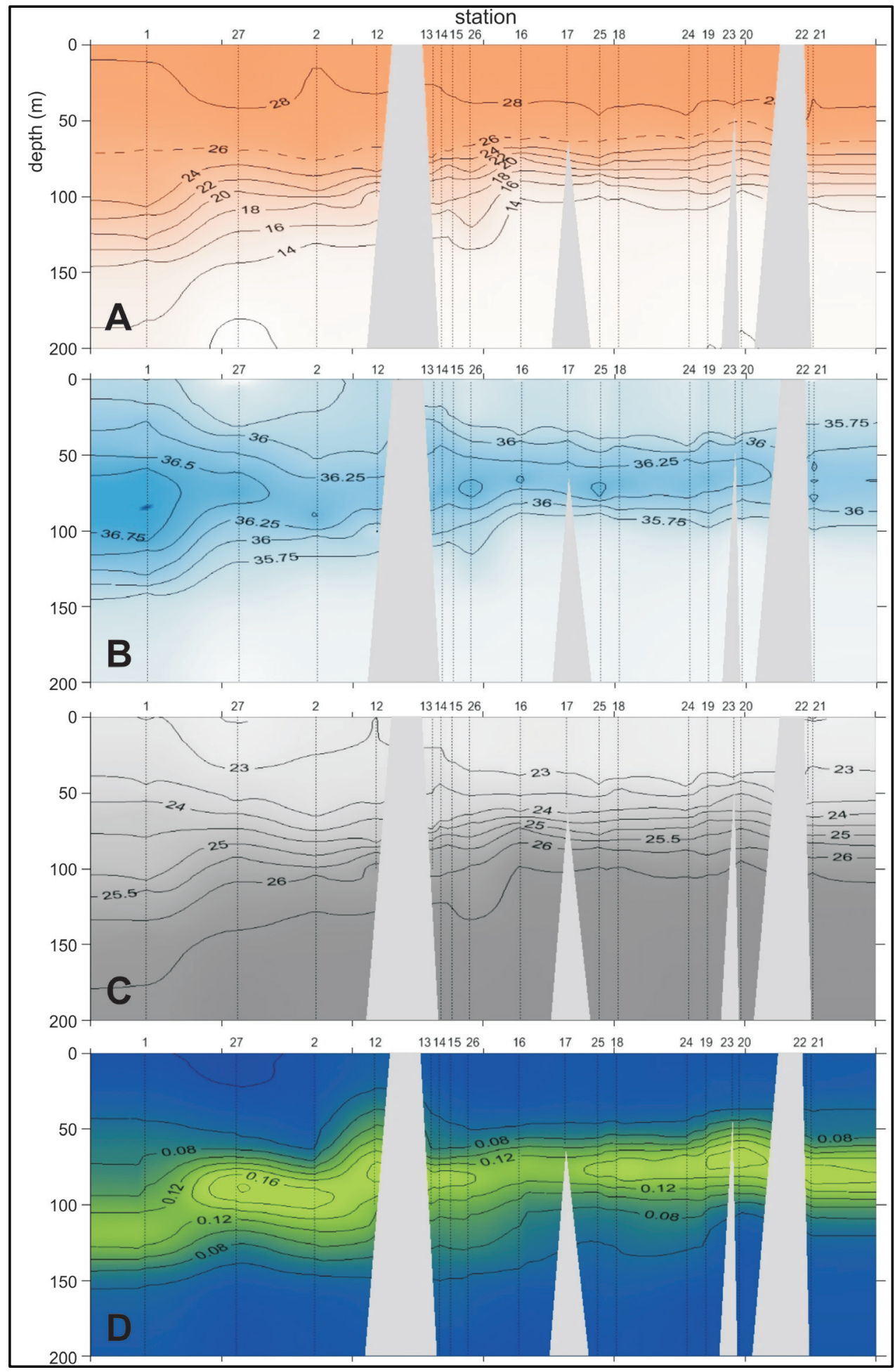

Figure 7. Isolines of salinity (A), temperature (B), density as $\sigma-t$ (C) and chlorophyll (D) 


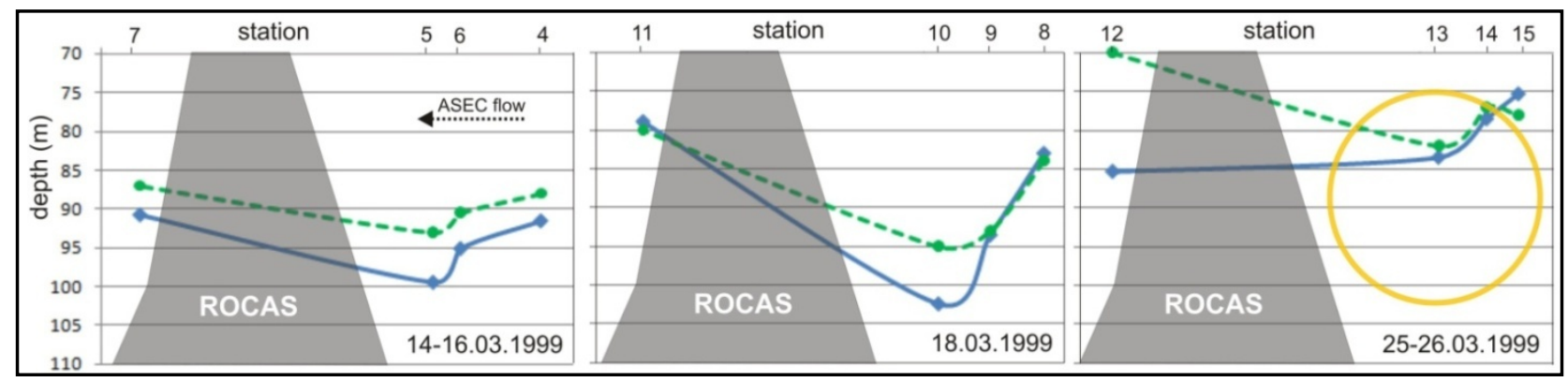

Figure 8. Variation in depth of the 25 isopycnal (solid line) and DCML (dashed line) in relation to the Rocas atoll. The yellow circle represents the orbit could be described by any particle at the pycnocline during an internal wave event, for this series was estimated a diameter $<30 \mathrm{~m}$

\section{Discussion}

The strong stratification of the oligotrophic ESW keeps a shallow nutrient poor mix layer with chlorophyll concentrations as low as in most tropical waters of the oceanic gyres[2]. Mean and integrated chlorophyll down to 200 meters depth varied respectively from $0,05-0,11 \mu \mathrm{g} . \mathrm{L}^{-1}$ and from 13,0 to $15,6 \mathrm{mg} \cdot \mathrm{m}^{-2}$, what is consistent with previous studies in the same region[12] and in similar hydrographic domains of Brazilian waters [9, 13]. DCML has been reported along pycnoclines off northeast Brazil by[16, 14], the second detected it near our study transect in depths of 0,1 to $1 \%$ of surface light $(77-120 \mathrm{~m})$. Two remarkable points in our study is the stretching of isopycnals and the gradualdeepening of the DCML westwards. The first may be assigned to the accumulation of ESW against seamount or continental slopes located further west of our sampling transect, shifting the flow of the ASEC northwards to form the North Brazil Current at approximately $35^{\circ} \mathrm{W}[17,18,10]$. The second is probably the consequence of the first.

Previous studies reported similar patterns of physical stratification in our study area, with the upper mix layer on the top of a conspicuous deep salinity maximum right above the top of the thermocline $[8,10,19]$. The upper mix layer of $25 \mathrm{~m}$ detected in our study (see Fig.7C) is much shallower than the mean of $62 \mathrm{~m}$ reported by[10] for the same region. Salinity certainly caused this shallowness of the mix layer because it increases downwards faster than the decrease of temperature, contributing for the sharp gradients in the pycnocline which facilitates even more the accumulation of chlorophyll rich particles at these layers. In fact the DCML followed closely the 25-26 isopycnals and the associated SSM.

It is relevant to mention peak concentrations of chlorophyll between $0,16-0,22 \mu \mathrm{g} . \mathrm{L}^{-1}$ occurred at salinities ranging from 36 to 36,7 which is slightly above the range of 35- 36 that characterize the nitrate rich SACW $[12,13]$. This is consistent with the general assumption that some cianobacteria cells, for instance Prochloroccocus, are unable to use nitrate as source of Nitrogen[5]. A way from islands and seamount slopes the most important source of ammonia for autotrophic cells comes from regeneration in the pelag ic microbial food web. Microzooplankton studies made in the same region based on $20 \mu \mathrm{m}$ net samples[20] and from Niskin bottles specifically at the DCML[21] revealed a highly diversified microzooplankton assemblage made of tintinids, naked ciliates, radiolarians and heterotrophic dinoflagellates. Total densities of these organisms range between 50 and 200 ind. $\mathrm{L}^{-1}[21]$ making them important producers of ammonia in tropical o ligotrophic waters [5].

The water flow interacting with topography certainly expose bacteria cells to additional ammonia regenerated by benthic organisms. Reference[22] concluded that ammonia regenerated by the benthic community of Caribbean islands accounted for the enhancement of phytoplankton primary production and chlorophyll accumulation in the wake side of the islands. The integrated chlorophyll over 100 meters in the wake of Rocas atoll were in fact higher $\left(12,26 \mathrm{mg} \cdot \mathrm{m}^{-2}\right)$ than upstream of the atoll $\left(8,18 \mathrm{mg} \cdot \mathrm{m}^{-2}\right)$. The same occurred but at a much longer distance downstream of Fernando de Noronha Is. Since bacteria cells use only reduced nitrogen sources recycled in the pelag ic system[23,5], we may argue they will take advantage of additional a mmonia recycled by the highly diversified benthic community in the summit of seamounts slopes around Rocas and FN[7].

Considering (i) growth rate of pico-procarionts (e.g., Prochlorococcus) ranges fro $\mathrm{m} 0.5$ to 1 divisions . day ${ }^{-1}$ [1], (ii) flow speed of the ASEC in our study transect is on average $30-60 \mathrm{~cm} . \mathrm{s}^{-1}$ [24] and (iii) the ca $27 \mathrm{~km}$ distant track over the slope of the atoll with $<100 \mathrm{~m}$, we conclude cells just arriving at Rocas will be exposed to additional a mmonia for 13 to 20 hours prior to being flushed out to deep waters downstream of the atoll. Nevertheless, with our data we may not conclude if the higher chlorophyll concentrations observed in the wake of Rocas is only due to ammonia fertilization or just accumulation of cells by physical processes.

Thickness of the DCML also changed along the horizontal plane. Fro $m$ the easternmost side of the transect (e.g., stn 20) peak chlorophyll concentrations started with $0.21 \mu \mathrm{g}$. $\mathrm{L}^{-1}$ decreasing gradually westwards. The DCML at station 17 located over a seamount was not as thick as in the deeper water columns, with maximum concentrations up to 0,1 $\mu \mathrm{g} . \mathrm{L}^{-1}$ near the bottom summit. In contrast to what has been reported over seamounts in the North Pacific[35, 36] uplift ing of isopycnals by (e.g.) Taylor columns were not distinguished (see Fig.7C) because it depends on the Coriolis force[38, 39], which is negligible near equatorial latitudes.

The 25 isopycnal and the thicker DCML observed downstream as well as upstream of the seamount were 
limited to depths below its summit. It has been reported significant increase of current velocities and ressuspension of organic particles near the bottom summit of seamounts due to tidal energy and/or internal waves[37, 36]. Except in rare occasions, none of these authors found higher chlorophyll concentrations trapped between specific isopycnals above seamounts. Yet, strong tidal currents over seamounts cause ressuspension of seston and increase dispersion rates, affecting the density of chlorophyll rich cells.

To estimate the amount of carbon available from DCML to the benthos of the Rocas atoll, we have to made some assumptions: (i) Chlorophyl:Carbon ratios of 0,0095 to 0,027:1 as proposed by[25] for central Atlantic waters, which is similar to the values found by[26] in the equatorial Pacific, (ii) a $14,8 \mathrm{~km}$ wide slope cross section, perpendicular to the currents at the $100 \mathrm{~m}$ isobath, (iii) DCML mean thickness of $25 \mathrm{~m}$ containing 0,1 to $0,2 \mu \mathrm{g}$ chlorophyll. $\mathrm{L}^{-1}$ and, (iv) ESW fluxes of 0,13 to $0,21 \mathrm{~Sv}$. Under these conditions, the DCML can provide the atoll ecosystem additional $210( \pm 170)$ metric tons of Carbon per day, exclusively from the pelag ic primary producers.

As stated earlier, the DCML here described follows closely the up and down movement of isopycnals. Internal waves cannot be ignored causing lifting up of pycnoclines over slopes of islands and seamounts. In tropical and subtropical oceans, internal waves usually have a mp litude $>50 \mathrm{~m}$, periods from tens of minutes to several hours and wavelengths from hundreds of meters to tens of kilometers; the orbital motion of water and particles have the largest diameter at the pycnocline and decreases up and downwards [32]. Internal waves have been detected year-round in the Western Equatorial Atlantic off northeast Brazil but more frequently between December and March by[27, 28]. The first authors detected internal waves every 11.4 to 13.8 hours between 30-78 meters, the second reported waves ranging usually from 5-8 meters high but 9 waves $20-23 \mathrm{~m}$ high were measured during a 18 days survey from March to April, i.e., during the same seasonal period of our investigation. Depths of pycnocline ranged for approximately 45 meters along our sampling transect (Fig.6).

The top layers of the nutrient-rich SACW on the wave's crest may reach up to $75 \mathrm{~m}$, which according to[14] correspond more or less to the $1 \%$ of surface light in this area. It has been demonstrated a strong diel variation in the expression of photosynthesis genes of Prochloroccocus collected in different diurnal periods in the equatorial Atlantic[29]. In a fixed position, internal waves may expose autotroph bacteria to highly variable light intensities. Reference[30] made similar assumptions regarding light intensification due to the lift of the pycnocline and the associated chloro- phyll maximum at Cobb Seamount in the Northeast Pacific. Since equatorial tidal currents are stronger and the potential for internal waves action against the slopes is great one may expect similar processes may account for the horizontal diffe rences of chlorophyll concentrations near seamounts and slopes along the FNR.
The annual rate of production of pico-photoautotrophs in oligotrophic oceans is constant and able to balance losses by grazing[31]. This is certainly what keeps the chlorophyll maximum throughout the year. Yet the peak chlorophyll concentrations here detected differed by two to three folds. Reference[1] reported a two-fold difference in depthintegrated cell densities of Prochloroccocus between afternoon and midnight in the equatorial and subtropical Pacific. Since our stations were sampled during the day and night, differences of peak ch lorophyll concentrations along the DCML might have been associated with sampling time.

Environmental controls derived from the interaction of water flow with topography along the FNR is complex and affect the balance between cell growth and losses that maintain DCML. Uplift ing of isopycnals by internal waves, changing light regime, and additional sources of nutrients, particularly ammonium from benthic communities, play a significant role on the dynamics of DCML and deserve a more investigation on time-spatial scales not covered here.

\section{ACKNOWLEDGEMENTS}

To Dr. S. Gruber, ch ief scientist of the expedition, for the invitation to this cru ises. Thanks are also due to the crew of the R/V Seward Johnson, for its support during field work. This work was supported by the Department of Biological Sciences of the State University of Santa Cruz (Bahia) and the Department of Systematics and Ecology of the Federal University of Paraíba.

\section{REFERENCES}

[1] Liu, H., Nolla H.A. and Campbell, L. 1997. Prochloroccocus growth rate and contribution to primary production in the equatorial and subtropical North Pacific Ocean. Aquatic Microbial Ecology 12(1): 39-47.

[2] Longhurst, A. R. 2007.Ecological Geography of the Sea (2nd ed). Academic Press, USA. 542p.

[3] Mann, K. H. and Lazier, J. R. N. 1996. Dynamics of marine ecosystems. Biological-physical interactions in the oceans, Blackwell Science Publ., Cambridge. pp 394.

[4] Partensky F., Blanchot J., Lantoine F., Neveux J. and Marie, D. 1996. Vertical structure of picophytoplankton at different trophic sites of the tropical northeastern Atlantic Ocean. Deep-Sea Research Part I, 43( 8): 1191-1213.

[5] Mackey, D.J., Blanchot, J., Higgins, H.W. and Neveux, J. 2002. Phytoplankton abundances and community structure in the equatorial Pacific. Deep-Sea Research Part II, 49(13- 14): 2561-2582.

[6] Eston, V.R., Migotto, A.E., Oliveira Filho, E.C., Rodrigues, S.A. and Freitas, J.C. 1986. Vertical distribution of benthic marine organisms on rocky coasts of the Fernando de Noronha Archipelago (Brazil). Bolm. Inst. Oceanogr. S. Paulo, 34:37-53.

[7] Paiva, P.C., Young, P.S. and Echeverria, C.A. 2007. The 
Rocas atoll, Brazil: a preliminary survey of the crustacea and polychaete fauna. Arq. Mus. Nac., Rio de Janeiro, 65(3):241-250.

[8] Castro Filho, B. M. and Miranda, L. B. 1998. Physical oceanography of the western Atlantic continental shelf located between $40^{\circ} \mathrm{N}$ and $34^{\circ} \mathrm{S}$. In: Robinson, A. R. \& Brink, K. H. (Eds.). The Sea - The Global Coastal Ocean - Regional Studies and Synthesis. John Wiley \& Sons, Inc. New York, USA, 11: 209 - 251 .

[9] Ekau, W. and Knoppers, B. A. 1996. Sedimentation processes and primary production in the continental shelf waters off East and Northeast Brazil. Cruise Report and First Re- sults. Publications of the Center of Tropical Marine Ecology, Bremen, Germany. 151 p.

[10] Travassos, P., Hazin, F., Zagaglia, J., Rocha, R. A. and Schober, J. 1999. Thermohaline structure around seamounts and islands of Northeast Brazil. Arch. Fish. Mar. Res., 47 (2/3): 211-222.

[11] Bourlès B., Gouriou Y.and Chuchla R.1999. On the circulation in the upper layer of the western equatorial Atlantic. J. Geophys. Res., 104(C9):21151-21170.

[12] Medeiros, C., Macedo, S.J., Feitosa, F.A.N. and Koening M.L. 1999. Hydrography and phytoplankton biomass and abundance of North-east Brazilian waters. Arch. Fish. Mar. Res., 47 (2/3): 133-151.

[13] Castro Filho, B.; Brandini, F. P.; Pires-Vanin, A.M.S. \& Miranda L.B. 2006. Multidisciplinary Oceanographic Processes on the Western Atlantic Continental Shelf between $4^{\circ} \mathrm{N}$ and $34^{\circ} \mathrm{S}$. In: Allan R. Robinson and Kenneth Brink (Eds), The Sea, Vol. 14A - The Global Coastal Ocean: Interdisciplinary Regional Studies and Syntheses, Harvard University Press, 259-293.

[14] Bröckel K.v \& and Meyerhöfer, M. (1999). Impacts of the Rocks of São Pedro and São Paulo upon the quantity and qualitity of suspended particulate organic matter. Arch. Fish. Mar. Res., 47 (2/3): 223-238.

[15] Baker, J.M. and Wolf, W.J. 1987. Biological Surveys of Estuaries and Coasts. Cambridge Univ. Press. pp. 472.

[16] Feitosa, F. F., Koening, M. L. \& Moura, G. F. 1996. Phyto-plankton composition and biomass. In: Ekau, W. \& Knop- pers, B. A. (Eds.), Sedimentation processes and primary production in the continental shelf waters off East and Northeast Brazil. Cruise Report and First Results. Publica- tions of the Center of Tropical Marine Ecology, Bremen,

[17] Silveira, I.C.A., de Miranda, L.B. and Brown, W.S. 1994.On the origins of the North Brazil Current. J. Geophys. Res., 99(C11): 22501-22512.

[18] Schott, F. A., Stramma, L. and Fischer, J.. 1995. The warm water inflow into the the western tropical Atlantic boundary regime, spring 1994. J. Geophys Res., 100 (C12) : 24745 24760 .

[19] Mémery, L, Arhan, M., Alvarez-Salgado, X. A,. Messias, M.-J., Mercier, H., Castro, C.G., Rios, A. F. 2000. The water masses along the western boundary of the south and equato-rial Atlantic. Progress in Oceanography, 47(1): 69-98.

[20] Nogueira, E.M.S., Sassi, R., Cordeiro, T.A. 2005. The Rhab-donellidae (Tintinnina:Oligotrichida) from Atol das
Rocas and Fernando de Noronha Archipelago, Southwestern Atlan-tic, Brazil. Arq. Ciên. Mar, 38: 93 - 104.

[21] Costa, A.E.S.F., Cordeiro, T.A., Rosa, R. S. 2010. O Proto-zooplâncton nos máximos de clorofila ao longo da cadeia de Fernando de Noronha, NE - Brasil, 1999. In: IV Congresso Brasileiro de Oceanografia, Rio Grande, RS, Brazil.

[22] Corredor J.E., Morell J., and Mendez, A. 1984. Dissolved Nitrogen, phytoplankton biomass and island mass effects in the Northeastern Caribbean Sea. Carib. J. Sci., 20 (3-4): 129-137.

[23] Rocap, G., Larimer, F., Lamerdin, J.E., Stilwagon, S. and Chisholm, S.W. 2001. From base pairs to niche differentia-tion: ecological insights from two complete genomes of Prochlorococcus. In: 2001 Aquatic Sciences Meeting, Vol. SS04 (Ackerman, J.D. and Twombly, S., Eds.), p. 36. Albu-querque, NM.

[24] Schott, F.A., Fischer, J. and Stramma, L., 1998. Transports and pathways of the upper-layer circulation in the western tropical Atlantic. J. Phys. Oceanogr, 28(10): 1904-1928.

[25] Behrenfeld, M.J., Boss, E., Siegel. D.A. and Shea, D.M. 2005. Carbon-based ocean productivity and phytoplankton physiology from space. Global Biogeochem. Cycles, 19, GB1006.

[26] Wang, X.J., Behrenfeld, M., Le Borgne, R., Murtugudde, R. and Boss, E. 2008. Regulation of phytoplankton carbon to chlorophyll ratio by light, nutrients and temperature in the equatorial Pacific Ocean: a basin-scale model. Biogeoscien-ces Discuss., 5: 3869-3903.

[27] Brandt, P., Rubino, A. and Fischer, J. 2002; Large-amplitude internal solitary waves in the North Equatorial Countercurrent. J. Phys. Oceanogr. 32 (5): 1567-1573.

[28] Ivanov, V.A., Pelinovsky, E.N., and Talipova, T.G. 1993. The long-time prediction of intense internal wave heights in the tropical region of the Atlantic. J. Phys. Oceanogr. 23 (9): 2136-2142.

[29] Hewson I., Poretsky, R.S., Tripp, H.J., Montoya, J.P. and Zehr, J.P. 2010. Spatial patterns and light-driven variation of microbial population gene expression in surface waters of the oligotrophic ocean. Environmental Microbiology, 12(7): 1940-1956.

[30] Comeau, L.A., Vezina, A.F., Bourgeois, M., and Juniper, S.K. 1995: Relationship between phytoplankton production and the physical structure of the water column near Cobb Seamount, northeast Pacific. Deep Sea Res., 42 : 993-1005.

[31] Karl, D.M. 1979. Measurements of microbial activity and growth in the ocean by rates of stable ribonucleic acid synthesis. Appl. Environ. Microbiol., 38 : 850-860.

[32] Alpers, W.R., Mitnik, L. Hock, L. and Chen, K.S.. 2012. The tropical and subtropical ocean viewed by ERS SAR. At http://www.ifm.zmaw.de/fileadmin/files/ers-sar/index.html (accessed 20.10.2012).

[33] Gomes, P.O., Gomes, B.S., Palma, J.J.C., Jinno, K. and de Souza, J.M. 2000. Ocean-continent transition and tectonic framework of the oceanic crust at the continental margin off NE Brazil: Results of LEPLAC project, in Atlantic Rifts and Continental Margins, Geophys. Monogr. Ser., vol. 115, ed ited by W. Mohriak and M. Taiwani, pp. 261-291, AGU, 
Washington, D. C., doi:10.1029/GM 115p0261.

[34] UNESCO. At http://whc.unesco.org/en/list/1000 (accessed 15.01.2012)

[35] Genin, A. and Boehlert, G. W. 1985. Dynamics of temperature and chlorophyll structures above a seamount: an oceanic experiment. Journal of Marine Research, 43: 907-924.

[36] Genin, A.; Dayton, P. K.; Londsdale, P. F. and Spiess, F. N. 1986. Corals on seamount peaks provide evidence of current acceleration over deep-sea top ography. Nature 322, 59-61.

[37] Eriksen, C. C. 1982. Observations of internal wave reflection off sloping bottoms. Journal of Geophysical Research, 87(C1): 525-538.

[38] Roden, G. I. (1987), Effect of seamounts and seamount chains on ocean circulation and thermohaline structure, in Seamounts, Islands, and Atolls, Geophys. Monogr. Ser., vol. 43, edited by B. H. Keating et al., pp. 335-354, AGU, Wash-ington, D. C., doi:10.1029/GM043p0335.

[39] White, M., Bashmachnikov, I., Aristegui, J. and Martins, A. 2007. Physical processes and seamount productivity. In: Pitcher, T.J., Morato, T., Hart, P.J.B., Clarck, M.R., Haggan, N. and Santos, R.S. (eds) - Seamounts: Ecology, Fisheries \& Conservation. Blackwell Publising, Oxford (UK), Iowa (USA), Victoria (Australia), pp: 65-84. 